The research program of the Center for Economic Studies (CES) produces a wide range of theoretical and empirical economic analyses that serve to improve the statistical programs of the U.S. Bureau of the Census. Many of these analyses take the form of CES research papers. The papers are intended to make the results of $\mathrm{CES}$ research available to economists and other interested parties in order to encourage discussion and obtain suggestions for revision before publication. The papers are unofficial and have not undergone the review accorded official Census Bureau publications. The opinions and conclusions expressed in the papers are those of the authors and do not necessarily represent those of the U.S. Bureau of the Census. Republication in whole or part must be cleared with the authors.

\title{
REGIONAL INCOME INEQUALITY AND INTERNATIONAL TRADE
}

\author{
Julie A. Silva * \\ Rutgers University
}

and

\author{
Robin M. Leichenko * \\ Rutgers University
}

CES 03-15 July, 2003 


\begin{abstract}
International trade is frequently cited as a cause of rising income inequality between individuals and across countries. Less attention has been paid to the effects of trade on inequality across regions within countries. Trade may enhance regional inequalities due to differences in regional trade involvement and in the prices of export and import-competing goods produced in different regions. This study investigates the effects of trade on income inequality across regions in the United States. Using both structural and price-based measures of regional trade involvement, we evaluate the effects of trade on inequality within and across states, the metro and nonmetro portions of the states, and the major Census regions. Across all states and across metro and nonmetro areas, we find that trade affects inequality primarily via import and export prices. In contrast to our expectations, however, a weaker dollar - more expensive imports and cheaper exports - is associated with a worsening of a state's position relative to other states, and greater inequality within a state. Across the Census regions, both our price and measures had significant effects, but the direction of these effects varied by region. Whereas most regions benefited from cheaper imports, states located in regions that are traditionally home to low-wage sectors, including the Southeast and South Central regions, were made relatively worse off by lower import prices and by greater orientation toward import-competing goods. Our findings reinforce notions about the uneven impacts of globalization and suggest that policy measures are needed to ensure that both the benefits and costs of international trade involvement are shared across regions.
\end{abstract}

Keywords: regional income inequality; economic globalization; regional development.

* This material is based upon work supported by the Cooperative State Research, Education, and Extension Service, U.S. Department of Agriculture, under Agreement No. 00-35401-9204. Any opinions, findings, conclusions, or recommendations expressed in this paper are those of the authors and do not necessarily reflect the view of the U.S. Department of Agriculture. This paper reports the results of research and analysis undertaken while the authors were research affiliates at the Center for Economic Studies at the U.S. Census Bureau. It has undergone a Census Bureau review more limited in scope than that given to official Census Bureau publications. Research results and conclusions expressed are those of the authors and do not necessarily indicate concurrence by the Census Bureau. It has been screened to insure that no confidential information is revealed. 


\section{INTRODUCTION}

There is considerable debate over the impacts of international trade on income inequality in the United States and other advanced countries. Based on the notion of comparative advantage, liberalization of international trade is expected to improve economic efficiency and raises aggregate welfare in all countries. Yet conventional trade theory also suggests that free trade may increase income inequality within countries by altering patterns of demand and wages for skilled and unskilled workers. The StorperSamuelson theorem, in particular, indicates that trade liberalization will benefit those factors of production that are relatively abundant in the each country and will harm factors that are relatively scarce (Rodrik 1997). Because advanced countries such as the United States have a relative abundance of skilled labor, increased trade is expected to raise both demand and wages for skilled workers. For unskilled labor, rising levels of trade, particularly between the United States and lower-wage developing countries, are expected to reduce both demand and wages (Wood 1994).

The theoretical relationship between trade and inequality has come under empirical scrutiny in recent years because growing levels of income inequality coincide with accelerating involvement in international trade (Sachs and Shatz 1994, 1996; Wood 1994; Bernard and Jensen 2000). Within the United States, recent research suggests that rising trade has contributed to widening dispersions between the wages of high-skill and low-skill workers by causing a decline in the relative demand for unskilled labor (Cline 1997, 2001, Bernard and Jensen 1995; Krugman 1995, Wood 1994; Borjas, Freeman, and Katz 1992). Other studies, however, find little empirical evidence of trade effects on wage premiums (Sachs and Shatz 1996; Lawrence and Slaughter 1993). Even among 
researchers who link trade to inequality, the severity of trade's effects is disputed. In a recent review of the U.S. national-level trade and inequality literature, Cline (2001) concludes that only 6 percent of rise inequality from the early 1970s to the early 1990s in the United States resulted from the influence of international trade. Others suggest, however, that this share may be as much as 20 percent (Wood 1998).

While national-level research on trade-inequality linkages is on going, examination of the relationship between foreign trade and income inequality at the regional level represents an important area for additional study. A number of regional studies have suggested that changing industrial structure is associated with increasing income inequality both within and across U.S. regions (Levernier et al. 1998; Drennan, et al. 1996; Fan and Casetti 1994; Eggers and Massey 1991). These studies have demonstrated that regions containing larger shares of more globalized industrial sectors have higher levels of income inequality. In addition, several studies have demonstrated that rural areas of the United States are disproportionately home to low-skill, low-wage, manufacturing sectors, and thus may be especially vulnerable to trade-related wage reductions (Leichenko and Silva 2003; Glasmeier and Leichenko 1999; Wojan 1999; Glasmeier et al. 1995). Yet little attention has been paid to the direct connections between international trade income inequality across U.S. regions. This study addresses these issues by evaluating the effects of international trade on patterns of income inequality within and across the U.S. states, the metro and nonmetro portions of the states, and the major Census regions.

In examining the linkages between international trade and regional income inequality, we address an issue of growing concern for national and regional policy 
makers. Economic globalization has lowered prices and increased the variety of goods available to U.S. consumers, but the possibility of trade-related job losses and wage reductions for low-skill workers continues to be a major concern for regions that contain large shares of traditional, lower-skill manufacturing industries. As Rodrik (1997) has noted, rising trade-related inequality in the absence of compensation measures, may result in marginalization of disadvantaged groups and pressures to increase trade protectionism. Attention to the differential regional effects of trade is a necessary first step in order to ensure that both the benefits and costs of trade are shared within and across regions.

The remainder of the article is organized as follows. In the next section, we review the literature on national and regional income inequality. In the third section we describe the construction of our regional trade and inequality measures. In the fourth and fifth sections, we examine patterns of U.S. regional inequality, and we present our empirical model of regional income inequality as a function of international trade and other factors. In the concluding section, we summarize our results and consider some of the policy implications of our findings.

\section{EMPIRICAL EVIDENCE ON U.S. INCOME INEQUALITY}

Studies of globalization and income inequality typically focus on either inequality of individuals or inequality across places. Both bodies of literature find evidence that income inequality is rising in the United States. Studies focused on individuals and workers have found that the polarization of skilled and unskilled worker wages drives the growth of U.S. income inequality. These studies have demonstrated that income and 
wages in the U.S. have become more unequal according to skill, even though gender and racial wage gaps have narrowed in recent years (Deere 2001; McCall 2001; Topel 1994). Across U.S. regions, studies have found that regional incomes have diverged since the mid-1970s (Fan and Cassetti 1994; Amos 1988). Regional and metro/nonmetro inequality grew especially rapidly during the 1980 s and continued to increase throughout the 1990 s (New York Times 2002; Levernier et al. 1998; Ngarambe et al 1998). In this section, we consider the empirical studies of U.S. income inequality across individuals and across regions, focusing primarily on inequality studies that either directly or indirectly incorporate the role of international trade.

\section{People-based Studies: Measuring Trade's Effects on Wages at the National Level}

People-based studies of income inequality are primarily national or cross-national in scope and emphasize the changes in demand and wages for skilled and unskilled workers. These studies, which are conducted mostly by trade and labor economists, use a variety of approaches and methods to explain earnings patterns and determine the sources of widening differentials in skill premiums. In addition to international trade, other determinants of rising skill differentials include technological change, immigration from poorer countries, deunionization, a declining real minimum wage, organizational change, government regulation, and gender and educational differences (Aghion et al. 1999; Bernard and Jensen 1999; Cline 1997; Gottschalk and Smeeding 1997; Topel 1994; Wood 1994). Many of the above studies find that skill-biased technological change is the dominant reason for growing inequality (Cline 2001; Aghion et al. 1999; Levy and Murnane 1992), but a number have shown that international trade is also a significant 
cause of widening skill differentials (Wood 1994, 1998; Borjas, Freeman and Katz 1992).

Several studies further argue that technology and trade are inter-related. Wood (1994), for example, suggests that skill-biased technological change represents a defensive laborsaving adaptation in response to increased competition. Aghnion et al. (1999) find that imported intermediate inputs bias the direction of technological change towards skillintensive industries.

Among those inequality studies that attempt to directly measure the contribution of trade, the findings are somewhat mixed. Trade's effects are frequently measured based on analyses of the factor content of imports and exports (Wood 1994; Borjas, Freeman and Katz 1992). Using this type of approach, Borjas, Freeman, and Katz (1992) estimate that trade accounts for $15 \%$ to $25 \%$ of the growing differential between college/noncollege wages. Extending the factor content method to incorporate technological changes and shifts in location of production of certain goods from advanced to developing countries, Wood $(1994,1998)$ estimates that trade accounts for $20 \%$ of the reduction in relative demand for unskilled labor in advanced countries. Using a general equilibrium approach - as opposed to partial equilibrium, econometric analysis used in the factor content studies - Cline (2001) finds smaller wage related effects of trade, estimating that trade causes $6 \%$ of wage differentials.

Other studies argue that empirical research on trade's contributions to rising inequality is inconclusive and has not yet provided convincing evidence that trade causes widening wage inequality in advanced economies (Sachs and Shatz 1996). Burtless (1995) further suggests that trade's effects on wages depend on the character of U.S. industries facing increased competition. In addition to differences in measuring trade- 
related effects, inconclusive findings at the national-level may result in the failure to take regional variation into account. As discussed below, international trade may have differential effects on inequality across regions as the result of differences in industry structure, income levels, state regulations, and other location-specific factors.

\section{Place-based Studies: Regional Perspectives on Income Inequality}

Studies of U.S. regional income inequality have frequently attempted to test Kuznets' hypothesis that regional levels of income inequality correspond to stages of economic development (Rey 2001; Fan and Casetti 1994; Nissan and Carter 1993; Amos 1988, 1989; Williamson 1965). According to Kuznets' inverted-U hypothesis, income inequality increases during early stages of economic development when wealth is concentrated in entrepreneurial households, and then moves towards convergence as wealth spreads across society (via higher wages). Williamson (1965) was the first to apply the inverted-U hypothesis to uneven U.S. regional development, finding evidence of regional income convergence through the 1950s. Amos (1988) updated Williamson's analysis through 1980 and found that regional income inequality continued to decrease through the mid-1970s at which time the trend towards convergence reversed.

Other regional studies of inequality also consistently find that U.S. regional income polarization has increased since the mid-1970s (Nissan and Carter 1993; Fan and Casetti 1994). Nissan and Carter (1993) profile regional income inequality from 1929 to 1990 using a modified Theil measure of relative inequality. They find that while national levels of inequality have increased since the mid-1970s, several major regions experienced a dramatic reduction in inequality. The Plains, Southeast, and Southwest 
regions fell from very large values in 1930 to comparatively much smaller levels in the 1980s. Nissan and Carter find that, by 1990, three subregions (New England, Mideast, and Far West) received higher shares of income in comparison to their population shares, while the other five regions (Great Lakes, Plains, Southeast, Southwest, and Rocky Mountain) experienced the opposite effect.

As was the case with the national studies, regional studies offer numerous explanations for rising inequality across places, including economic restructuring, immigration from poorer countries, government regulation, and market-induced transformation of local economies (McCall 1998, 2001; Morrill 2000; Glickman 1998; Kodras 1997; Fan and Casetti 1994). Many place-based studies find that the erosion of low-skill wages has contributed to increases in income inequality (e.g., McCall 1998, 2001; Lee 1999; Glickman 1998; and Kodras 1997) - a finding that echoes work at the national-level. Although globalization is mentioned as a possible cause of growing regional inequality, there has been relatively little empirical testing of the direct relationship between international trade and inequality across regions.

Two studies that partially address this issue are those of Karoly and Klerman (1994) and Bernard and Jensen (2000), both of which consider the effects of trade and other factors on wage inequality across states in the 1970s and 1980s. Both of these studies find that international imports played a significant role in determining wage inequality, yet the direction of the import effect varies depending upon the type of measure used. Using structural measures of trade (import and exports shares of production) Karoly and Klerman (1994) find that male wage inequality at the state level rises as the share of imports in the U.S. economy increases. By contrast, using a price- 
based measures (import and export exchange rates), Bernard and Jensen (2000) find that rising (rather than falling) import prices are associated with increases in state wage inequality.

Several other studies of regional income inequality in the U.S. have demonstrated that trade-related economic restructuring is associated with increasing income polarization (McCall 2001; Morrill 2000; Fan and Casetti 1994). Fan and Cassetti (1994) find, for example, that spatial economic restructuring and sectoral shifts contributed to growing regional income polarization over the period from 1950 through 1989. Other studies provide case study and descriptive evidence of the structural sources of inequality and downward pressure on wages (e.g., Glickman 1998; and Kodras 1997). Kodras (1997) presents five case studies to show how poverty and inequality are geographically produced by regional responses to global and national economic forces. She argues that local social relations interact with market structures to influence the distribution of opportunities and risks across regions. In addition, Kodras shows how governmental taxing and spending policies of the 1980s left low-income workers vulnerable to wage erosion, rising unemployment, and declining benefits, thereby expanding national income disparities. Glickman (1998) echoes many of Kodras' findings. He also notes that regional development and inequality are associated with regional competitiveness in the international marketplace.

Our study expands upon regional work in this area by incorporating two different types of direct measures of regional trade involvement into the analysis of regional income inequality. We also expand upon prior work by paying attention to inequality across both metro and nonmetro areas, and across different Census regions. A few place- 
based studies have examined inequality across U.S. metropolitan areas (Odland and Ellis 2001; Angel and Mitchell 1991), across metro and nonmetro areas (Levernier et al. 1998; Tolbert and Lyson 1992) and across different regions (Nissan and Carter 1993), but these studies have not directly explored the role of international trade in fostering urban-rural or cross-regional differences. As noted earlier, we suspect that manufacturing trade may have especially detrimental effects on rural areas and on regions that are home to many low-wage, low-skill industries.

\section{MEASURING TRADE AND INEQUALITY ACROSS REGIONS}

\section{Regional Trade Involvement}

Most of the studies reviewed above use either priced-based measures of international trade, which relate changing prices of goods to labor market outcomes, or industry-level measures of trade involvement, especially share of production in tradeintensive sectors. In developing our measures of regional trade involvement, we draw from both these approaches to develop two types of measures of regional trade pressures. As described below, our price-based measures entail creation of regional export and import exchange rates, while our structural measures involve creation of export and import orientation level indicators for regional economies. Data sources used to construct the measures include national-level data on U.S. exchange rates, U.S. industrial exports by country of destination, and U.S. industrial imports by country of origination, as well as state-level data on manufacturing export shipments and shares of industrial production by 
4-digit manufacturing sector derived from the U.S. Census, Longitudinal Research

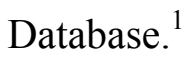

\section{Price Measures}

Drawing upon the methodology developed in the study by Bernard and Jensen (2000) we develop two price-based measures of state involvement in international trade: state import exchange rates and state export exchange rates. The process for construction of these measures is illustrated for the state-level variables. The metro and nonmetro variables were constructed in an identical fashion, using data for either the metro portions of each state (i.e., the metro counties combined) or the nonmetro portions of each state (i.e., the nonmetro counties combined).

We first constructed industry import exchange rates for each 4-digit manufacturing industry. The 4-digit SIC industry import exchange rates are given by the sum of real exchange rates indices (U.S. dollar/foreign currency) across countries

\footnotetext{
${ }^{1}$ The national export and import data were obtained from the databases developed by Robert Feenstra $(1996 ; 1997)$. The exchange rate data were obtained from the International Financial Statistics database (International Monetary Fund 2002). The state and county data were obtained using the Longitudinal Research Database of U.S. Census (LRD). The LRD contains data on total shipments, foreign exports and other variables for all manufacturing firms included in the U.S. Annual Survey of Manufactures and the U.S. Census of Manufactures for the period between 1967 and 1997. Confidentiality concerns preclude public release of the LRD data. For this reason, the sorting, processing, and compilation of the state trade database, and all subsequent data analysis, took place at the Census Bureau, Regional Data Center (RDC) laboratory in Washington, D.C.
} 
weighted by that country's share in imports in the industry during that year.

1. IMPEX $X_{i}=\sum I M P_{\text {ctry }, i} / I M P_{i} * E X C H_{c t r y}$

We then constructed state import exchange rates using the weighted sum of industry import exchange rates with the weights given by the share of the industry in total shipments from the state. ${ }^{2}$

2. $I_{s t}=\sum T V S_{s t, i} / T_{V S} * E X C H I M_{i}$

The state export exchange rates were constructed in a similar fashion. For state export exchange rates, the first step entailed calculation of an export exchange rate for each 4-digit industry as the weighted sum of real exchange rates indices (U.S. dollar/foreign currency) ${ }^{3}$ across countries weighted by each country's share in exports in

${ }^{2}$ Weights are based on the Manufacturing Census, performed every five years. Each Census is used to weight the data for the census year and for the two years before and two years after the Census. So for example, the 1977 Census data used to weight county import exchange rates data for 1975, 1976, 1977, 1978, 1979. The dataset is missing counties in Rhode Island due to a coding problem in the LRD. It is also excludes counties with no manufacturing establishments.

${ }^{3}$ The exchange rates are nominal exchange rates deflated by GDP deflators in foreign currency per U.S. dollar normalized to be 100 in 1993. 1993 was selected as a base year because GDP data was the most complete for all countries in the data set during this year. 
the industry during that year.

3. $E X C H E X_{i}=\sum E X P_{c t r y, i} / E X P_{i} * E X C H_{c t r y}$

The second step used the above industry exchange rates to calculate state exchange rates. The state export exchange rate is the weighted sum of 4-digit SIC industry export exchange rates weighted by the share of the 4-digit SIC industry in total manufacturing exports from the state. ${ }^{4}$

4. $X_{s t}=\sum E X P_{s t, i} / E X P_{s t} * E X C H E X_{i}$

We use these exchange rate indices as proxy measures of changing prices for imported and export goods across the continental states.

Structural Measures

Based on the methodology presented in Leichenko and Silva (2003), we also develop two structural measures of regional trade involvement These measures provide an indication of the export and import orientation of the industries in which a state's economy is specialized. These measures, which were calculated for each state (and for the metro and nonmetro portions of each state), are intended as estimates of the degree to which a state's industries are internationally oriented. We again illustrate the process of

\footnotetext{
${ }^{4}$ Due to a lack of industry export data in earlier years, we used weights based on the 1987 Census for the years from 1972-1989; weights based on the 1992 Census were used for the years (1989-1994).
} 
construction of these measures using the state-level variables.

Construction of the trade orientation measures also entailed a two-step process. The national import orientation of each 4-digit SIC industry was calculated as the total value of import shipments divided by the total value of shipments in that industry that are available in the U.S. market (i.e., U.S. shipments plus imported shipments minus export shipments).

5. $I M P O R_{i}=I M P_{i} /\left(T V S_{i}+I M P_{i}-E X P_{i}\right)$

Import orientation for a state was then calculated as a function of the weighted sum of IMPOR weighted by the share of the industry in the total shipments from a state.

6. $I O R_{s t}=\sum T V S_{s t, i} / T V S_{s t} * I M P O R_{i}$

For exports, the national export orientation of each 4-digit SIC industry was first calculated as the value of export shipments in the industry divided by the total value of shipments in that industry.

7. $E X P O R_{i}=E X P_{i} / T V S_{i}$

Next, export orientation for a state was calculated as function of the weighted sum of EXPOR, weighted by the share of the 4-digit SIC industry in total export shipments from the state. 
8. $E O R_{s t}=\sum E X P_{s t, i} / E X P_{s t} * E X P O R_{i}$

Taken together, the exchange rate and trade orientation measures provide a broad gauge of trade pressures at the state level. These measures have the advantage of reflecting exogenous price and structural shocks to the manufacturing plants in a region. Before proceeding with the analysis, however, two limitations of the trade measures should be noted. First, because the measures are developed from the Longitudinal Research Database, they are limited to manufacturing sector trade and do not capture trade in services or raw agricultural products. However, because the manufacturing sector is often implicated in trade-related wage reductions, the focus on manufacturing is merited and is consistent with most other studies in this area (e.g., Bernard and Jenson 2000; Wood 1994). Second, data availability limited our study to the period from 1972 through 1994, a period in which SIC consistent trade data is available (Feenstra 1996, 1997). Our study thus covers a period of extensive trade-related, manufacturing restructuring, but does not incorporate rising inequality during the latter half of the 1990s associated with the stock market boom during the heyday of the "New Economy."

\section{Measuring Regional Inequality}

Three commonly used measures of regional inequality include the Gini coefficient (Morrill 2000; Ngarambe et al 1998; Partridge et al 1996; Levernier et al 1995; Alesina and Rodrik 1994), the coefficient of variation (Nissan and Carter 1999; Fan and Casetti 1994; Amos 1988; Williamson 1965), and Theil's inequality index (Rey 2001; Conceicão 
and Ferreira 2000; Nissan and Carter 1993; Tolbert and Lyson 1992). Applications using each of these measures find consistent evidence of increasing regional inequality across the United States since the 1970s, although the precise patterns of regional inequality vary somewhat depending on the measurement used (see Litchfield (1999), Cowell (1995), Cowell and Jenkins (1995), and Blackwood and Lynch (1994) for detailed reviews of the strengths and weaknesses of each measure).

In selecting a measure of inequality for the present study, we required a measure that allowed analysis of regional income patterns over time and also permitted investigation of inequality both within and across regions. For these reasons, we measure patterns of inequality using the modifications of Theil's index developed by Nissan and Carter (1993). The modified Theil measures of inequality allow examination of changes in inequality on an annual basis, whereas measures such as the Gini or Lorenz curves may only be constructed with Census data on a decennial basis. ${ }^{5}$ The modified Theil measures also allow inequality to be assessed both across states (interstate inequality) and within states (intrastate inequality). By contrast, the coefficient of variation, which may be calculated on an annual basis, only provides a measure of across state inequality. Inequality Across States

The Theil measure of interstate inequality provides an indicator of the relative distribution of income across the states by measuring the proportion of each county's

\footnotetext{
${ }^{5}$ We found that the Theil measure closely parallels the spatial patterns of inequality revealed by the Gini coefficient in comparison with the Gini figures for census years $(1980,1990)$.
} 
income share relative to the nation to its population share relative to the nation and summing these figures for each state. The interstate inequality measure is constructed as:

9. $J_{g}=1 / n_{g} \sum p_{i} / y_{i}$

The states in the United States are denoted by $\mathrm{R}_{\mathrm{g}}, \mathrm{g}=1,2, \ldots 48 ; \mathrm{p}_{i}$ is the county $i$ share of national population; $\mathrm{y}_{i}$ is the county $i$ share of national income; and, $\sum \mathrm{p}_{i}=\sum \mathrm{y}_{i}=$ 1 , and $n_{\mathrm{g}}$ is the number of counties in a state $\mathrm{R}_{\mathrm{g}}$. When $\mathrm{J}_{\mathrm{g}}=1$ a state has an equal proportional share of income to population (i.e., equality is reached when a state's share of income is exactly proportional to its share of population; income transfers and other redistributional issues are not addressed.) When $J_{g}>1$, the state has less than its proportional share of national income (i.e., its population share is larger than its income share). When $\mathrm{J}_{\mathrm{g}}<1$, the state receives a larger share of income than its share of population.

Inequality with States

Inequality within states (intrastate inequality) measures the inequality among the counties which comprise a state. With this measure, national income and population shares of each county in a state are compared with that state's share of national income and population. This measure weights counties according to the overall state population and income. The measure of intrastate inequality is constructed as:

10. $J_{r}=1 / n_{g} \sum\left(p_{i} / P_{g}\right) /\left(y_{i} / Y_{g}\right)$ 
where the states in the United States are again denoted by $\mathrm{R}_{\mathrm{g}}, g=1,2, \ldots 48, \mathrm{p}_{i}$ is the county $i$ share of national population where $\sum_{i} \mathrm{p}_{i}=1$, and $\mathrm{y}_{i}$ is the county $i$ share of national income where $\sum_{i} \mathrm{y}_{i}=1$. For each state $\left(\mathrm{R}_{\mathrm{g}}\right)$, its population share of the nation is $\mathrm{P}_{\mathrm{g}}$ and its income share of the nation is $\mathrm{Y}_{\mathrm{g}}$, and $n_{\mathrm{g}}$ is the number of counties in state $\mathrm{R}_{\mathrm{g}}$. In this equation, the county share of national population $\left(\mathrm{p}_{i}\right)$ and the county share of national income $\left(\mathrm{y}_{i}\right)$ is now compared with the state's share of national population $\mathrm{P}_{\mathrm{g}}$ and income $\mathrm{Y}_{\mathrm{g}}$ such that $\sum_{i} \mathrm{p}_{i} / \mathrm{P}_{\mathrm{g}}=\sum_{i} \mathrm{y}_{i} / \mathrm{Y}_{\mathrm{g}}=1$. Higher values for $\mathrm{J}_{r}$ imply that a state has higher levels of inequality across its counties.

The measures for the metro and nonmetro portions of the states were constructed in a similar fashion. The metro and nonmetro interstate measures reflect inequality across the metro and nonmetro portions of all states, while the metro and nonmetro intrastate measures indicate inequality within the metro and nonmetro portions of each state.

\section{PATTERNS OF REGIONAL INEQUALITY}

\section{Changes in Inequality Over Time}

Theil Index values for the inequality measures were constructed using data on income and population from the Regional Economic Information System (REIS) series produced by the US Census (U.S. Census 2001). Examination of changes in mean state Theil values over time (Figure 1) indicates that inequality between and within states increased over the study period, and that interstate inequality was consistently greater than intrastate inequality. These findings are consistent with other studies, which have also found that inequality across U.S. regions tends to be greater than inequality within 
U.S. regions (Nissan and Carter 1993; Theil 1967;). However, there is evidence that the two measures converged between 1989 and 1994. During that period interstate inequality dipped but within-state inequality continued its steady climb (see Figure 1).

Figure 2 illustrates changes in mean Theil values over time for the metro and nonmetro portions of all states. For metro portions, interstate inequality tends to be much higher than intrastate inequality during any given year. This indicates that there is more inequality across urban counties throughout the U.S. than across urban counties within specific states (i.e., urban county income/population shares tend to be closer to their state mean values). Both inequality measures for urban areas are also relatively stable over time. For nonmetro areas, the patterns and trends are quite different. Intrastate inequality tends to be consistently higher than interstate inequality, indicating that income differences between rural counties and their state mean values tend to be much greater than income differences across rural areas throughout the country. Rural intrastate inequality also appears to be increasing over time, suggesting that rural counties in many states are becoming worse off relative to the mean values for their state. Although rural interstate inequality is also growing over time, the overall change is less dramatic.

\section{Patterns of Inequality Across States}

Figures 3 and 4 and Table 1 illustrate the levels of interstate inequality in 1972 and the mean changes in interstate inequality for the period from 1972 through 1994. In 1972, six states (Nevada, New Jersey, Connecticut, Massachusetts, California, and Wyoming) and the District of Columbia had income shares that were greater than their population shares (i.e. interstate inequality measures of less than 1). New England (with 
the exception of Maine), the Great Plains region (with the exception of Missouri), the Mountain West region (with the exception of Utah), and the West Coast region had relatively equal population to income shares. The states with the highest interstate inequality values (i.e., income shares that were substantially lower than their population shares) were clustered in the southern portion of the United States. These are the regions which have maintained relatively large shares of the nation's low-wage industries, such as apparel and textiles manufacturing.

Examination of figure 4 reveals that many states with relatively equal population to income shares in 1972 became worse off over time. In particular, many states in the Great Plains, Mountain West, and West Coast regions became relatively more unequal over the study period (i.e., their population shares increased relative to their income shares). Montana, in particular, shows the greatest increase in inequality of population shares to income, followed by North Dakota, Arizona, Nebraska and Idaho. Decreases in inequality tended to take place in states with high initial 1972 levels, particularly in the South Central and Southeast regions. During this same time period, the southern states experienced robust economic development and lost relatively fewer manufacturing jobs than other regions, both of which might account for some of the decreasing levels of inequality (Glasmeier and Leichenko 1996).

\section{Patterns of Inequality within States}

Figures 5 and 6 (and Table 1) show that inequality within states (intrastate inequality) in 1972 lacked the regional patterns evidenced by the between-state measure. In 1972, the states with the highest levels of intrastate inequality were Missouri, New 
York, Georgia, Michigan, and Virginia. All of these states display sharp differences in incomes levels between their highly urbanized counties (most of which are part of large metropolitan areas) and their rural counties. The states with the lowest levels of intrastate inequality in 1972 were North Dakota, Montana, Wyoming, Rhode Island, Kansas, and Massachusetts. With the exception of Massachusetts and Rhode Island, states characterized by low intrastate inequality in 1972 were sparsely populated with a limited manufacturing sector. In Massachusetts and Rhode Island, the legacies of progressive economic policies and inclusive social institutions that foster high degrees of social capital may help to explain the lower levels of inequality (Duncan 1999).

Between 1972 and 1994, within-state inequality generally increased. That said, the South Central and Southeastern states experienced decreases in intrastate inequality relative to the rest of the nation. However, since their initial levels of intrastate inequality were so high, this decrease brought them more in line with the rest of the nation (see Table 1). The Northeast and Middle Atlantic states, with the notable exception of New York, also experienced a widespread decrease in within-state inequality. As seen with the interstate inequality measure, the West Coast and Great Plains regions of the United States became more unequal over time. Nebraska experienced the highest growth in intrastate inequality, followed by Washington, Arizona, and the Dakotas. Interestingly, our findings of growing intrastate inequality in the Mountain West and Great Plains contrast with those of Levernier et. al. (1996) and Morrill (2000) who used Gini coefficients to measure within state inequality and found reductions in inequality in these regions. One possible explanation for these differing results is that our measure is sensitive variation in regional inequality in a state, whereas the Gini measure provide an 
indication of inequality across individuals and families within a state. Our results comport with the work of Angel and Mitchell (1992), who find evidence of growing intraregional wage inequality in the North Central Census region. Our findings also echo those of Karoly and Klerman (1994), who find that the Great Plains region experienced a large increase in wage inequality for both men and women during the 1980s.

\section{EMPIRICAL ANALYSIS AND RESULTS}

To further explore the causes of changing patterns of income inequality across the states and the potential linkages between international trade and regional inequality, we developed and estimated an empirical regression model. Our model is based on the traditional Kuznets regional inequality model used by Williamson (1965), Amos (1988) and others, whereby inequality is a function of per capita income and urbanization. We expand the model to include manufacturing indicators and international trade indicators, as follows:

11. income inequality $=$ fn(income measures, urbanization measures, manufacturing measures, international trade measures)

The dependent variable, income inequality, is measured using both the Theil interstate inequality measure $\left(\mathrm{J}_{g}\right)$ and the Theil intrastate inequality measure $\left(\mathrm{J}_{r}\right)$. Concerning the explanatory variables, theory and previous empirical results lead us to expect certain relationships between the model's explanatory variables and regional inequality. The Kuznets' hypothesis predicts that higher per capita income decreases 
inequality in later stages of development. Therefore we expect a negative relationship between our income measures (per capita income and per capita income squared) and inequality: rising incomes should be associated with reduced inequality both across and within states. Concerning urbanization, previous studies have found that urban areas are characterized by higher levels of inequality. This leads us to expect a positive relationship between inter- and intrastate inequality and our two urbanization measures (metropolitan population share and population density).

We have added manufacturing measures (manufacturing shares of employment and manufacturing earnings per worker) to the basic Kuznets model because changing conditions of manufacturing (e.g., deindustrialization, de-unionization) are frequently cited as key factors driving regional inequality. Manufacturing jobs tend to be highly unionized, thus offering higher returns to low-skill labor and narrowing the gap between skill differentials. We therefore expect a negative relationship between our manufacturing measures and our two measures of inequality.

Finally, our international trade measures include export exchange rate, export orientation, import exchange rate and import orientation. The expected relationship between inequality and our export variables is mixed. For our interstate inequality measure, the expected effects of our export variables are negative. Increased exporting due to either higher exchange rates (i.e., dollar depreciation which makes U.S. exports cheaper abroad) and/or greater export orientation is expected to bring additional income to a state, thereby making that state better off relative to other states (i.e., reducing its interstate inequality score). For intrastate inequality, however, the expected effects of our export variables are uncertain. On the one hand, we expect that increases in exporting due 
to higher exchange rates and/or greater export orientation of state economies might place upward pressure on wages for highly skilled workers, thereby increasing inequality within a state. This type of positive relationship between exports and intrastate inequality would be consistent with the work of Bernard and Jensen $(1995,1997)$ who find that exporters are more skill intensive and pay higher wages than non-exporters. On the other hand, researchers have also found that exporting firms pay higher wages to all types of workers, which would reduce intrastate inequality, suggesting a negative relationship between our export variables and inequality (Bernard and Jensen 2000).

For imports, we need to consider the effects of exchange rate movements separately from the effects of changes in import orientation. A lower import exchange rate (i.e., a stronger dollar) should result in cheaper imports to the U.S. and hence more competition for domestic producers. If a state contains industries that experience substantial import penetration, and imports are generally produced with less-skilled labor, then inequality within the state should rise and a state should also become worse off relative to other states. The expected relationship between import exchange rates and both measures of inequality is therefore negative. For import orientation, greater exposure to the global economy places competitive pressures on firms, which should result in adoption of cost-saving measures such as use of labor saving technologies, thereby reducing both employment and wages and making highly import-exposed states more unequal and worse off relative to other states. The expected relationship between import orientation and both inequality measures is therefore positive.

The inequality models are first estimated for all states, for the urban (metro) portions of the states, and for rural (nonmetro) portions of the states. The models are then 
estimated for the states in each Census regions. All of the model groups are estimated as a panel, incorporating fixed effects based on deviations from individual (state) and year means. Use of individual fixed effects controls for variables that do not change over time for individual states (e.g., location and natural amenities), while use of time period fixed effects controls for factors such as oil price shocks and national economic cycles, which affect all states during any given year. All of the model groups are estimated using annual data for the period from 1972 through 1994.

\section{Results for All States}

Table 2 presents the results for both inter- and intrastate inequality across all states and across the urban (metro) and rural (nonmetro) portions of the states. Focusing first on our control variables, the signs on per capita income (PCI) and PCIsquared are somewhat mixed. For all states, PCI has the expected negative effect in both the interstate and intrastate model, indicating that the counties in a state within higher average income tend to be relatively better off than counties in other states (i.e., lower interstate inequality) and have less inequality within the state (i.e., lower intrastate inequality). Interestingly, across metro areas, PCI has a positive effect in both models. This result indicates that metro counties in states with higher PCI tend to be worse off in comparison to metro counties elsewhere and tend have more inequality among themselves. These findings are likely a reflection of the high levels of inequality found between urban and suburban counties located in large, relatively wealthy metro areas of many states. Finally, for the rural models, PCI has the expected negative effect in the interstate model, but a positive effect in the intrastate model. Rural counties in states 
within higher PCI tend to be better off in comparison to rural counties elsewhere, but also tend to have higher inequality across the rural counties within the state. The effects of PCI-squared tend to temper the effects of higher PCI in most cases (i.e., PCI-squared has the opposite sign of $\mathrm{PCI})$.

Concerning our urbanization indicators, both population shares and population density have the expected positive effects on inequality across and within states. Our manufacturing variables, by contrast, have unanticipated positive results. These results indicate that higher shares of manufacturing employment and higher manufacturing earnings are associated with a worsening of a state's position relative to other states (i.e., higher interstate inequality), and with higher inequality within a state. The results, which contrast our expectation that higher manufacturing shares would reduce inequality, may partially reflect the effects of industrial restructuring, whereby areas with higher manufacturing shares have also been highly vulnerable to job loss. The parameter coefficient on manufacturing earnings is positive and significant for all state areas and for urban areas, but negative for rural areas. For the interstate models, these results likely reflect decentralization of manufacturing from urban to rural areas, whereby mediumskill (and relatively high-wage) manufacturing jobs have left urban areas and have become increasingly concentrated in rural areas. As a result, high manufacturing earnings improve the position of a state's rural counties relative to other rural counties throughout the country, and also reduce inequality across the rural counties of each state. For the intrastate models, the positive relationship between inequality and manufacturing in the all state area and urban models may be due, in part, to high levels of service industry 
jobs. As noted by McCall (2001), higher manufacturing wages tend to widen the gap between low-skill workers and other workers in areas with a large service sector.

Turning to the trade variables, we include in the models both contemporaneous values and one year lagged values for all four trade variables. One year lags are included because prior research suggests that trade's effects on regional economies may not necessarily be felt immediately due to price and wage stickiness, new investment lags, and other factors (Leichenko 2000; Cronovich and Gazel 1998). In general, our results for the trade exchange rate variables are more consistent than for the trade orientation variables. The parameter coefficients on export exchange rates and their one-year lags are consistently positive and significant for states, state urban areas, and state rural areas, indicating that a higher exchange rate is associated with higher inter- and intrastate inequality. Because higher exchange rates imply that the dollar is weaker, these results suggest that lower prices for export goods produced in a state lead to more inequality between counties within a state and a worsening of a state's position relative to other states. For intrastate inequality, this result is consistent with trade theory's prediction that trade increases relative demand for skilled labor and thus increases intraregional inequality (e.g., Cline 1997, Wood 1994). For interstate inequality, however, this result contrasts with our expectation that greater export sales (as a result of lower prices) would enhance the position of states relative to other states. One possible explanation for this finding is that export goods producers may also tend to rely on intermediate imported inputs, such that a weaker dollar, while lowering prices for export products, also raises costs of purchasing imported inputs. A second possible explanation is that increased export sales may not necessarily be associated with higher relative incomes. Export 
growth has been found in other studies to result in lower regional employment as the result of increases in labor productivity in the absence of economic growth (Leichenko 2000; Markusen et al. 1991).

Import prices also have consistent effects, but these effects again run counter to our expectations. We had expected that a lower import exchange rate, which translates into cheaper imports due to a stronger dollar, would increase both inter- and intrastate inequality by decreasing relative demand for unskilled labor. Instead we find that the parameter coefficients on import exchange rates and their one-year lags are consistently positive, signifying that cheaper imports generally improve a state's position relative to other states, and also reduce intrastate inequality. Once again, there are two possible explanations for our findings. Cheaper imports may be helping firms that rely on imported intermediate inputs, thereby increasing demand and earnings for both high and low skill labor. In addition, cheaper imports many have a positive, competitive effect by increasing productivity, lowering consumer prices, and thereby reducing inequality within and between states. The former explanation is consistent with recent evidence suggesting that higher prices for imported inputs are highly detrimental to importconsuming firms (Wall Street Journal 2003), while the latter interpretation is consistent with the conventional argument of gains from trade, whereby trade liberalization leads to lower prices and across the board welfare enhancement.

The effects of trade orientation on regional inequality are also somewhat mixed. Export orientation's effects are often insignificant, but there is some evidence that greater degrees of export-orientation for a state's industries decrease both types of inequality in urban and rural counties. In both sets of models, the effects of contemporaneous export 
orientation are negative and significant for urban areas, while the one-year lag of export orientation is negative and significant for rural areas. This negative relationship for urban and rural inequality is consistent with the prediction that increased export orientation makes regions better off relative to other regions and also leads to lower intraregional inequality because exporting industries pay higher wages to both skilled and unskilled workers (Bernard and Jensen 1999).

Returns on import orientation are also mixed, with negative effects for the contemporaneous variable, but positive effects for the lagged variable. In the models for all states, the positive coefficients on the lagged import orientation variable represent the dominant (larger) effect. This suggests that states with industrial structures that are more oriented towards import-competing goods tend to be worse off relative to other states and also tend to be more unequal. This conforms to our initial expectation that import oriented industries would be more vulnerable to inequality. However, for the urban and rural models, the negative sign on the contemporaneous import orientation variable is the dominant effect. This denotes that, for urban and rural areas, having industrial structures that are more oriented towards import-competing goods have less inequality relative to other regions. In addition to the explanations presented above, our mixed results for our trade variables may also be a function of differences across regions. We explore the effects of trade on inequality across different regions below.

\section{Results for Census Subregions}

Tables 3 and 4 present the results for the inequality models across the Census regions. Because the results are similar for the two measures, we emphasize the interstate models in our discussion. Focusing on the trade variables, we find that trade enhanced 
inequality is some regions and dampened it in others. Regional responses to changing export and import prices are especially varied. The relationship between export exchange rates and inequality was positive for the Middle Atlantic, Southeast, and Southwest. These findings mirror the results from our national models. By contrast, the New England, Great Lakes and West Coast Census subregions demonstrated a significant negative relationship between higher export exchange rates and inequality. This indicates that lower export prices for goods produced in these regions made the regions better off relative to the rest of the nation. These different export price impacts across Census subregions could be explained, in part, by the nature of regional industries and their exports. For example, the West Coast and Great Lakes both have high concentrations of SIC 37 (transportation), which traditional pays higher wages. Other regional export studies have also noted positive feedbacks between export growth and regional economic performance in the West Coast and in SIC 37 (Leichenko 2000; Leichenko and Coulson 1999).

The results from our import exchange variable were also varied, with four of the Census regions showing evidence of a negative relationship between import exchange rates and interstate inequality and four regions showing the opposite effect. Cheaper imports (lower import exchange rates) lead to increases in inequality scores in the New England, Southeast, South Central and Mountain West regions: import price competition made states in these regions worse-off relative to other regions. By contrast, the states in the Middle Atlantic, Great Lakes, Great Plains, and Southwest regions demonstrate a positive and significant relationship between import exchange rates and interstate inequality: cheaper imports made states in these regions better off relative to other 
regions. One possible reason for the differences in import price effects across regions is the relative dependence of a region's industries on imported intermediate inputs. Regions with high concentrations of industries that rely on intermediate imported inputs would benefit from cheaper imports, whereas regions with industries that compete directly with imported goods would be hurt by cheaper imports.

The returns to our export orientation variables are positive and significant for New England and the Great Lakes. This suggests that, for states in these regions, economies with greater export orientation became worse off relative to states in other regions. Interestingly, both of these regions displayed a negative relationship between export exchange rates and inequality (i.e., cheaper exports helped these regions). This difference in the price versus structural effects of exports suggest that while lower export price led to increased sales and higher wages in these regions, greater export orientation, which may be associated with higher degrees of competition and adoption of labor saving technologies, led to a relative worsening of a state's position relative to other states in these regions. Only in the Mountain West was the relationship between export orientation and inequality negative. Export orientation made states in this region relatively better off in comparison with other regions.

Finally, with regard to import orientation, the effects on inequality are positive and significant for the Middle Atlantic, South Central, Southeast, and Mountain West regions. This suggests that greater orientation toward import-competing goods made the states in these regions relatively worse off. It is noteworthy that the South Central and Southeast regions, both home to many of the nation's low-wage manufacturing sectors were also hurt by falling prices for import-competing goods. We can thus conclude that 
both cheaper imports and greater orientation toward import-competing goods hurt the relative position of states in these two regions. The opposite relationship holds for the Great Lakes and New England regions, where greater orientation toward importcompeting sectors decreased the relative inequality of states in the regions. Interestingly, for the Great Lakes, both cheaper imports and greater import orientation, improved the position of states in the region. As suggested above, the importance of intermediate imported inputs, particularly in the transportation sector (SIC 37), may help to explain this consistent, yet counterintuitive result.

\section{CONCLUSIONS}

Globalization is frequently cited as a cause of increasing inequality among individuals and across countries. Less attention has been paid to the possible effects of globalization on income inequality across regions. Here we explored the effects of one aspect of globalization — regional involvement in international trade - on inequality within and across regions of the United States.

Our findings indicate that levels of inequality both within and across U.S. states are increasing over time, and that the effects of trade appear to be similar for both intraand interstate inequality. Across all states and across state-metro and state-nonmetro areas, our results suggest that the inequality enhancing effects of trade operate most consistently via export and import prices. However, the direction of these trade price effects generally ran counter to our expectations. We had expected that lower prices for a state's exports and higher prices for competing imports would enhance the position of a state relative to other states and would reduce inequality within a state. Instead, we found 
the opposite effects: cheaper exports and more expensive competing imports made a state relatively worse off in comparison to other states and increased inequality within a state. Although contrary to our expectations, the results for exports are, in fact, consistent with the findings of other studies which have demonstrated that export growth is not necessarily associated with improvement of a state's overall economic position (Leichenko 2000; Markusen et al. 1991). Similarly, while the results for imports contrasted our expectations, these results are consistent with conventional notions about gains from trade, whereby higher import prices have detrimental economic effects as the results of higher prices for both imported intermediate inputs and higher prices for final consumer goods.

Across the subregions, the effects of trade were more mixed. Most regions benefited from cheaper imports. The Southeast and South Central regions, however, both of which are dominated by low-wage, import-sensitive manufacturing industries, were made worse of by both cheaper imports and by greater orientation toward production of import competing goods. By contrast, the Great Lakes, a region containing industries that are highly reliant on imported intermediate inputs, was helped by cheaper imports and greater orientation toward production of goods in import-competing sectors. On the export side, cheaper exports hurt most regions, but helped states located on the West Coast, a traditionally highly export-oriented region. Interestingly, for the Great Lakes and New England, we found contrasting price versus structural effects of exports: cheaper exports benefited states in both of these regions but greater export orientation hurt the states in these regions. 
In terms of implications for policy, our results indicate that trade's effects are complex and do not necessary lend clear support for either a pro-free trade or a protectionist position. For imports, we find support for a pro-free trade argument across all states, but support for trade protectionism in regions that are traditionally producers of import-competing goods. These results are consistent with the idea that free trade has overall welfare-enhancing effects, but negative effects for specific industries and regions (O’Brien and Leichenko 2003; Conroy and Glasmeier 1993). Similarly, for exports, our results indicate that programs to increase sales of a region's exports may have detrimental effects in some regions.

What our analysis ultimately reveals is that regional income inequality cannot be controlled via trade policy. Restricting trade will lead to higher import prices and increased inequality across states, but promotion of free trade (via cheaper exports) also appears to result in more inequality for many regions. These findings add support to the suggestions of Richardson (1995) and others that policy prescriptions to mitigate tradeinduced income inequality often have little to do with trade policy. Rather, social policy is necessary to offset the inequality-enhancing effects of trade (Rodrik 1997; Wood 1994).

Our mixed findings on the regional effects of trade are also consistent with a growing recognition in the broader literatures on the regional, social, and environmental dimensions of globalization, that no consensus may be possible concerning the benefits and costs of globalization, once distributional factors are take into account (O'Brien and Leichenko 2003; Wade 2001; Deardorff and Stern 2000; Kapstein 2000). This again affirms the suggestion that social policy is necessary to ensure that both the costs and 
benefits of globalization are fairly distributed not only across individual workers and across countries, but also across regions within countries. 


\section{REFERENCES}

Angel, D.P., and J. Mitchell. 1991. Intermetropolitan wage disparities and industrial change. Economic Geography 62 (2):124-135.

Aghion, P., E. Caroli, and C. Garcia-Penalosa. 1999. Inequality and economic growth:

The perspective on new growth theories. Journal of Economic Literature 37:1615-1660.

Alesina, A., and D. Rodrik. 1994. Distributive politics and economic growth. The Quarterly Journal of Economics 109:465-490.

Amos, O.M., Jr. 1988. Unbalanced regional growth and regional income inequality. Regional Science and Urban Development 18:549-566.

1989. An inquiry into the causes of increasing regional income inequality in the United States. Review of Regional Studies 19 (2):1-12.

Bernard, A., and J.B. Jensen. 1995. Exporters, jobs, and wages in U.S. manufacturing: 1976-87. Brookings Papers on Economic Activity: Microeconomics:67-119.

—. 1997. Exporter, skills-upgrading, and the wage gap. Journal of International Economics 47:3-31.

- 1999. Exceptional exporter performance: Cause, effect, or both? Journal of International Economics 47:1-25.

. 2000. Understanding increasing and decreasing wage inequality. In The Impact of International Trade on Wages, edited by R. Feenstra. Chicago: National Bureau of Economic Research and University of Chicago Press.

Blackwood, D.L., and R.G. Lynch. 1994. The measurement of inequality and poverty: A 
policy maker's guide to the literature. World Development 22 (4):567-578.

Borjas, G.J., R.J. Freeman, and L.F. Katz. 1992. On the labor market effects of immigration and trade. In Immigration and the Work Force., edited by G. Borjas and R. Freeman. Chicago: University of Chicago Press.

Burtless, G. 1995. International trade and the rise in earnings inequality. Journal of Economic Literature 30:800-816.

Cline, W. 1997. Trade and Income Distribution. Washington, D.C.: Institute for International Economics.

- 2001. Trade, immigration, and wage distribution. In The Causes and Consequences of Increasing Inequality, edited by F. Welch. Chicago: University of Chicago Press.

Conceicão, P., and P. Ferreira. 2000. The young person's guide to the Theil index: Suggesting intuitive interpretations and exploring analytical applications. University of Texas Inequality Project Working Paper 14.

Conroy, Michael E., and Amy K. Glasmeier. 1993. Unprecedented disparities, unparalleled adjustment needs: Winners and losers on the NAFTA 'Fast Track.' Journal of InterAmerican Studies and World Affairs 34:1-37.

Cowell, F.A. 1995. Measuring Inequality. 2nd ed. Hemel Hempstead: Harvester Wheatsheaf.

Cowell, F.A., and S.P. Jenkins. 1995. How much inequality can we explain? A methodology and application to the United States. The Economic Journal 105:421-430.

Cronovich, R., and R. Gazel. 1998. Do exchange rates and foreign incomes matter for 
exports at the state level? Journal of Regional Science 38:639-657.

Deardorff, A. V. and R. M. Stern, eds. 2000. Social Dimensions of U.S. Trade Policy. Ann Arbor, MI: The University of Michigan Press.

Deere, D. 2001. Trends in wage inequality in the United States. In The Causes and Consequences of Increasing Inequality, edited by F. Welch. Chicago: University of Chicago.

Drennen, M., E. Tobier, and J. Lewis. 1996. The interruption of income convergence and income growth in large cities in the 1980s. Urban Studies 33 (1):63-82.

Duncan, C. 1999. Worlds Apart: Why Poverty Persists in Rural America. New Haven: Yale University Press.

Eggers, M.L., and D.S. Massey. 1991. The structural determinants of urban poverty: A comparison of whites, blacks, and hispanics. Social Science Research 20:217-255.

Fan, C.C., and E. Casetti 1994. The spatial and temporal dynamics of U.S. regional income inequality, 1950-1989. Annals of Regional Science 28:177-196.

Feenstra, R.C. 1996. U.S. imports, 1972-1994: Data and concordances. Working Paper No. 5515, National Bureau of Economic Research, Cambridge, MA.

_ 1997. U.S. exports, 1972-1994, with state exports and other U.S. data. Working Paper No. 5990, National Bureau of Economic Research, Cambridge, MA.

Glasmeier, A.K., A. Kays, J.W. Thompson, and R. Gurwitt. 1995. Branch Plants and Rural Development in the Age of Globalization. State Overview Series, Rural Economic Policy Program, The Aspen Institute.

Glasmeier, A.K., and R.M. Leichenko. 1996. From free market rhetoric to free market reality: The future of the U.S. South in an era of globalization. International 
Journal of Urban and Regional Research 20 (4):601-615.

1999. What does the future hold? What globalization might mean for the rural South. Southern Rural Sociology 15:59-83.

Glickman, N. 1998. Prosperity and inequality among America's cities and regions. Center for Urban Policy Research Working Paper No.146.

Gottschalk, P., and T.M. Smeeding. 1997. Cross-national comparisons of earnings and income inequality. Journal of Economic Literature 35:633-687.

International Monetary Fund (2002). International Financial Statistics CD-Rom. Washington, D.C: International Monetary Fund.

Kapstein, E.B. 2000. Winners and losers in the global economy. International Organization 54 (2):359-384.

Karoly, L.A., and J.A. Klerman. 1994. Using regional data to reexamine the contribution of demographic and sector changes to increasing U.S. wage inequality. In The Changing Distribution of Income in an Open U.S. Economy, edited by J. H. Bergstrand et al. Amsterdam: North-Holland.

Kodras, J.E. 1997. The changing map of American poverty in an era of economic restructuring and political realignment. Economic Geography 73 (1):67-93.

Krugman, P. 1995. Growing world trade: Causes and consequences. Brookings Paper on Economic Activity: $327-362$

Lawrence, R.Z., and M.J. Slaughter. 1993. Trade and U.S. wages: Giant sucking sound or small hiccup? In Brookings Papers on Economic Activity: Microeconomics. Washington, D.C.: Brookings Institution.

Lee, D.S. 1999. Wage inequality in the United States during the 1980s: Rusing dispersion 
or falling minimum wage? The Quarterly Journal of Economics:977-1023.

Leichenko, R.M. 2000. Exports, employment, and production: A causal assessment of U.S. states and regions. Economic Geography 76 (4):303-325.

Leichenko, R.M. and N.E. Coulson. 1999. Foreign industrial exports and state manufacturing performance. Growth and Change 30: 479-506.

Leichenko, R.M., and J.A. Silva. 2003. International trade, employment, and earnings: Evidence from U.S. rural counties. Discussion Paper, CES 03-12. U.S. Department of Commerce, Center for Economic Studies.

Levernier, W., D.S. Rickman, and M.D. Partridge. 1995. Variation in U.S. state income inequality: 1960-1990. International Regional Science Review 18 (3):355-378.

Levernier, W., M.D. Partridge, and D.S. Rickman. 1998. Differences in metropolitan and nonmetropolitan U.S. family income inequality. Journal of Urban Economics 44:272-290.

Levy, F., and R.J. Murnane. 1992. U.S. Earnings levels and earnings inequality: A review of recent trends and proposed explanations. Journal of Economic Literature 30:1333-1381.

Litchfield, J.A. 1999. Inequality: Methods and Tools. Available from www.worldbank.org/poverty/inequal/methods/litchfie.pdf.

Markusen, A. R., Noponen, H., and Driessen, K. 1991. International trade, productivity, and U.S. regional job growth: A shift-share interpretation. International Regional Science Review 14.1:15-39.

McCall, L. 1998. Spatial routes to gender wage (in)equality: Regional restructuring and wage differentials by gender and education. Economic Geography 74 (4):379- 
404.

-2001. Complex Inequality: Gender, Race, and Class in the New Economy. New York: Routledge.

New York Times. 2002. Census finds rising tides, and many who missed boat. June $17^{\text {th }}$, p.B1.

Morrill, R. 2000. Geographic variation in change in income inequality among U.S. states, 1970-1990. The Annals of Regional Science 34:109-130.

Ngarambe, O., S.J. Goetz, and D.L. Debertin. 1998. Regional economic growth and income distribution: County-level evidence for the U.S. South. Journal of Agriculture and Applied Economics 30 (2):325-337.

Nissan, E., and G. Carter. 1993. Income inequality across regions over time. Growth and Change 24:303-319.

- 1999. Spatial and temporal metropolitan and nonmetropolitan trends in income inequality. Growth and Change 10:407-429.

Odland, J., and M. Ellis. 2001. Changes in the inequality of earnings for young men in Metropolitan labor markets, 1979-1989: The effects of declining wages and sectoral shifts within an efficiency wage framework. Economic Geography 77 (2):148-179.

O’Brien, K. and R. Leichenko. 2003. Winners and losers in the context of global change. Annals of the Association of American Geographers 93: 89-103.

Partridge, M.D., D.S. Rickman, and W. Levernier. 1996. Trends in U.S. income inequality: Evidence from a panel of states. The Quarterly Review of Economics and Finance $36(1): 17-37$. 
Rey, S.J. 2001. Spatial analysis of regional income inequality. Regional Economics Applications Laboratory Discussion Paper 01-T-9. Available from http://ideas.repec.org/p/wpa/wuwpur/0110002.htm

Richardson, J.D. 1995. Income inequality and trade: How to think, what to conclude. Journal of Economic Perspectives 9 (3):33-55.

Rodrik, D. 1997. Has Globalization Gone Too Far? Washington, D.C.: Institute for International Economics.

Sachs, J.D., and H.J. Shatz. 1994. Trade and jobs in U.S. manufacturing. Brookings Papers on Economic Activity:1-84.

Sachs, J.D., and H.J. Shatz 1996. U.S. Trade with developing countries and wage inequality. AEA Papers and Proceedings 86 (2):234-239.

Theil, H. 1967. Economics and Information Theory. Amsterdam: North-Holland Publishing Company.

Tolbert, C.M., and T.A. Lyson. 1992. Earnings inequality in the Nonmetropolitan United States: 1967-1990. Rural Sociology 54 (4):494-511.

Topel, R.H. 1994. Regional labor markets and the determinants of wage inequality. The American Economic Review 84 (2):12-22.

U.S. Census. 2001. Regional Economic Information System, 1969-1999. Washington, D.C.: Bureau of Economic Analysis, Regional Economic Measurement Division. Wade, R. 2001. Global inequality: Winners and losers. The Economist (April 28, 2001) 359 (8219):72-74.

Wall Street Journal. 2003. The steel tariff's cost, February 23, p. A14. 
Williamson, J.G. 1965. Regional inequality and the process of national development. Economic Development and Cultural Change 13:3-45.

Wojan, T.R. 1999. Functional skill requirements of manufacturing in the rural South. Southern Rural Sociology 15:104-138.

Wood, A. 1994. North-South Trade, Employment, and Inequality: Changing Fortunes in A Skill-Driven World. Oxford: Clarendon Press. 1998. Globalisation and the rise in labour market inequalities. The Economic Journal 108:1463-14. 


\begin{tabular}{|c|c|c|c|c|}
\hline \multirow{3}{*}{ Region } & \multicolumn{2}{|c|}{ Interstate Inequality $(\mathrm{Jg})$} & \multicolumn{2}{|c|}{ Intrastate Inequality (Jr) } \\
\hline & 1972 & 1994 & 1972 & 1994 \\
\hline & All & All & All & All \\
\hline United States & 1.2097 & 1.2528 & 1.1256 & 1.1840 \\
\hline New England & 1.0713 & 1.0226 & 1.0406 & 1.0643 \\
\hline Middle Atlantic & 1.0456 & 1.0647 & 1.1647 & 1.1982 \\
\hline Southeast & 1.4118 & 1.3359 & 1.2062 & 1.2207 \\
\hline Great Lakes & 1.1615 & 1.2324 & 1.1811 & 1.2254 \\
\hline South Central & 1.5800 & 1.4480 & 1.1878 & 1.1850 \\
\hline Great Plains & 1.1588 & 1.3141 & 1.0926 & 1.2152 \\
\hline Mountain West & 1.1501 & 1.3389 & 1.0683 & 1.1680 \\
\hline Southwest & 1.3165 & 1.4510 & 1.1447 & 1.2364 \\
\hline West Coast & 0.9889 & 1.1691 & 1.0622 & 1.1960 \\
\hline
\end{tabular}

Source: Author's calculations using data from REIS (Census 2001). 
Table 2. Inequality Regression Results, All States, State Metro Areas, and State Nonmetro Areas (1972-1994) ${ }^{\mathrm{a}}$

\begin{tabular}{|c|c|c|c|c|c|c|}
\hline \multirow[b]{4}{*}{ Variable } & \multicolumn{6}{|c|}{ Dependent Variable } \\
\hline & \multicolumn{3}{|c|}{ Interstate Inequality (Jg) } & \multicolumn{3}{|c|}{ Intrastate Inequality (Jr) } \\
\hline & $\begin{array}{r}\text { All State } \\
\text { Areas } \\
\end{array}$ & $\begin{array}{l}\text { Metro } \\
\text { Areas } \\
\end{array}$ & $\begin{array}{r}\text { Nonmetro } \\
\text { Areas } \\
\end{array}$ & $\begin{array}{r}\text { All State } \\
\text { Areas } \\
\end{array}$ & $\begin{array}{c}\text { Metro } \\
\text { Areas } \\
\end{array}$ & $\begin{array}{r}\text { Nonmetro } \\
\text { Areas }\end{array}$ \\
\hline & param & param & param & param & param & param \\
\hline PCI & $-0.0001 * *$ & $1.0 \mathrm{E}-05 * *$ & $-4.1 \mathrm{E}-06$ & $-2.2 \mathrm{E}-05 * *$ & $5.0 \mathrm{E}-05 * *$ & $5.0 \mathrm{E}-05 * *$ \\
\hline PCISQ & $1.9 \mathrm{E}-09 * *$ & $-9.3 \mathrm{E}-10 * *$ & $-2.4 \mathrm{E}-10$ & $4.5 \mathrm{E}-10 * *$ & $-8.5 \mathrm{E}-10 * *$ & $-7.6 \mathrm{E}-10 * *$ \\
\hline Metro Pop. & $3.4459 * *$ & & & $1.4301 * *$ & & \\
\hline Pop. Dens. & $0.0010 * *$ & $0.0003 * *$ & $0.0014 * *$ & $0.0003 * *$ & $9.4 \mathrm{E}-05$ & $0.0007 * *$ \\
\hline Manuf. Sh. & $0.3763 * *$ & $1.1530 * *$ & $1.3202 * *$ & $0.6329 * *$ & $0.5532 * *$ & $0.6529 * *$ \\
\hline Manuf. Earn. & $0.0044 * *$ & $0.0032 * *$ & $-0.0050 * *$ & $0.0034 * *$ & 0.0004 & $-0.0047 * *$ \\
\hline Export Exch. & $0.0009 * *$ & $0.0013 * *$ & $0.0018 * *$ & $0.0004 * *$ & $0.0004 * *$ & $0.0013 * *$ \\
\hline ExpexchL1 & $0.0008 * *$ & $0.0013 * *$ & $0.0020 * *$ & $0.0004 * *$ & $0.0005 * *$ & $0.0014 * *$ \\
\hline Import Exch. & $0.0016 * *$ & $0.0027 * *$ & $0.0030 * *$ & $0.0013 * *$ & $0.0011 * *$ & $0.0014 * *$ \\
\hline ImpexchL1 & 0.0004 & $0.0044 * *$ & $0.0039 * *$ & -0.0004 & $0.0015 * *$ & $0.00210 * *$ \\
\hline Export Orient. & -0.0314 & $-0.1691 * *$ & 0.1193 & -0.0077 & $-0.0954 * *$ & 0.0525 \\
\hline ExporientL1 & 0.0152 & -0.0672 & $-0.3567 * *$ & 0.0556 & -0.0117 & $-0.2772 * *$ \\
\hline Import Orient. & -0.1859 & $-0.6529 * *$ & $-0.5062 * *$ & $-0.1412 * *$ & $-0.3165 * *$ & $-0.3824 * *$ \\
\hline ImporientL1 & $0.2826 * *$ & $0.2914 * *$ & $0.3623 * *$ & $0.1996 * *$ & $0.1583 * *$ & $0.2065 * *$ \\
\hline
\end{tabular}

${ }^{a}$ All models are estimated as a panel with fixed state and year effects.

**Significant at the .05 level.

Source: Authors' calculations at Center for Economic Studies, U.S. Census Bureau. 
Table 3. Results for Interstate Inequality by Census Region (1972-1994) ${ }^{a}$

\begin{tabular}{|c|c|c|c|c|c|c|c|c|c|}
\hline \multirow[b]{3}{*}{ Variable } & \multicolumn{9}{|c|}{ Dependent Variable: Interstate Inequality (Jg) } \\
\hline & $\begin{array}{r}\text { New } \\
\text { England } \\
\end{array}$ & $\begin{array}{r}\text { Middle } \\
\text { Atlantic } \\
\end{array}$ & Southeast & $\begin{array}{c}\text { Great } \\
\text { Lakes } \\
\end{array}$ & $\begin{array}{r}\text { South } \\
\text { Central } \\
\end{array}$ & $\begin{array}{c}\text { Great } \\
\text { Plains } \\
\end{array}$ & $\begin{array}{r}\text { Mountain } \\
\text { West } \\
\end{array}$ & Southwest & $\begin{array}{r}\text { West } \\
\text { Coast } \\
\end{array}$ \\
\hline & param & param & param & param & param & param & param & param & param \\
\hline PCI & $-0.0001 * *$ & $-8.6 \mathrm{E}-05 * *$ & $-0.0002 * *$ & $-5.7 \mathrm{E}-05 * *$ & $-0.0002 * *$ & $-0.0001 * *$ & $-6.6 \mathrm{E}-05 * *$ & $-0.0003 * *$ & $-0.0001 * *$ \\
\hline PCISQ & $2.0 \mathrm{E}-09 * *$ & $7.2 \mathrm{E}-10 * *$ & $2.7 \mathrm{E}-09 * *$ & $-2.8 \mathrm{E}-10$ & $3.2 \mathrm{E}-09 * *$ & $9.4 \mathrm{E}-10$ & $1.9 \mathrm{E}-10$ & $6.5 \mathrm{E}-09 * *$ & $1.4 \mathrm{E}-09$ \\
\hline Metro Pop. & $4.3696^{* *}$ & $2.3026 * *$ & $4.1671 * *$ & $4.1758 * *$ & $3.7952 * *$ & $2.8786^{* *}$ & $2.5094 * *$ & -0.1565 & $4.6097 * *$ \\
\hline Pop. Dens. & $0.0008 * *$ & $-1.9 \mathrm{E}-05$ & -0.0002 & -0.0024 & 0.0010 & $0.0026 *$ & $0.0041 * *$ & $0.0169 * *$ & $0.0030 * *$ \\
\hline Manuf. Sh. & $0.5395 * *$ & -0.1494 & $2.1494 * *$ & 0.0305 & $1.3502 * *$ & 0.1440 & $2.3285^{*}$ & $8.5016^{* *}$ & 1.0784 \\
\hline Manuf. Earn. & $0.0114 * *$ & $0.0049 * *$ & 0.0053 & 0.0015 & $0.0212 * *$ & $0.0236 * *$ & 0.0007 & $-0.0086 *$ & $-0.0116 * *$ \\
\hline Export Exch. & 0.0002 & 0.0007 & 0.0002 & $-0.0027 * *$ & -0.0006 & 0.0013 & 0.0002 & $0.0074 * *$ & $-0.0022 * *$ \\
\hline ExpexchL1 & $-0.0015 * *$ & $0.0015 * *$ & $0.0014 * *$ & -0.0012 & 0.0006 & 0.0004 & 0.0002 & -0.0035 & $-0.0021 * *$ \\
\hline Import Exch. & $-0.0013 * *$ & $0.0053 * *$ & 0.0013 & $0.0040 * *$ & $-0.0031 * *$ & $0.0034 * *$ & 0.0011 & $0.0032 * *$ & -0.0019 \\
\hline ImpexchL1 & $-0.0016 * *$ & 0.0006 & $-0.0028 * *$ & $-0.0020 * *$ & 0.0008 & $-0.0021 * *$ & $-0.0050 * *$ & 0.0048 & -0.0004 \\
\hline Export Orient. & $0.3515 * *$ & -0.0963 & 0.2264 & 0.0548 & 0.1020 & -0.4915 & -0.2200 & 0.4822 & -0.0583 \\
\hline ExporientL1 & 0.1228 & 0.1305 & -0.0478 & $0.5061 * *$ & -0.2015 & 0.2343 & $-1.6097 * *$ & 0.7402 & -0.0898 \\
\hline Import Orient. & $-0.4923 * *$ & -0.1281 & $1.5290 * *$ & $-0.7741 * *$ & $2.1250 * *$ & 0.5292 & -0.3490 & 0.0970 & 0.0834 \\
\hline ImporientL1 & -0.4564 & $0.3879 * *$ & $-0.4131 * *$ & 0.3844 & 0.1925 & -0.1223 & $2.7552 * *$ & -0.6100 & 0.1197 \\
\hline
\end{tabular}

${ }^{\mathrm{a}}$ All models are estimated as a panel with fixed state and year effects.

**Significant at the .05 level.

Source: Authors' calculations at Center for Economic Studies, U.S. Census Bureau. 
Table 4. Results for Intrastate Inequality by Census Region (1972-1994) ${ }^{\text {a }}$

\begin{tabular}{|c|c|c|c|c|c|c|c|c|c|}
\hline \multirow[b]{3}{*}{ Variable } & \multicolumn{9}{|c|}{ Dependent Variable: Intrastate Inequality (Jr) } \\
\hline & $\begin{array}{r}\text { New } \\
\text { England }\end{array}$ & $\begin{array}{c}\text { Middle } \\
\text { Atlantic }\end{array}$ & Southeast & $\begin{array}{c}\text { Great } \\
\text { Lakes }\end{array}$ & $\begin{array}{r}\text { South } \\
\text { Central } \\
\end{array}$ & $\begin{array}{c}\text { Great } \\
\text { Plains }\end{array}$ & $\begin{array}{r}\text { Mountain } \\
\text { West } \\
\end{array}$ & Southwest & $\begin{array}{r}\text { West } \\
\text { Coast }\end{array}$ \\
\hline & param & param & param & param & param & param & param & param & param \\
\hline PCI & $-2.6 \mathrm{E}-05 * *$ & $6.5 \mathrm{E}-06$ & $-5.1 \mathrm{E}-07$ & $3.6 \mathrm{E}-06$ & $-4.4 \mathrm{E}-05 * *$ & $-6.9 \mathrm{E}-05 * *$ & $1.4 \mathrm{E}-05$ & $-0.0002 * *$ & $-6.1 \mathrm{E}-06$ \\
\hline PCISQ & $4.5 \mathrm{E}-10 * *$ & $-1.8 \mathrm{E}-10$ & $2.2 \mathrm{E}-10$ & $-1.3 \mathrm{E}-10$ & $1.2 \mathrm{E}-09 * *$ & $1.0 \mathrm{E}-09$ & $-2.9 \mathrm{E}-10$ & $4.0 \mathrm{E}-09 * *$ & $2.4 \mathrm{E}-10$ \\
\hline Metro Pop. & $1.9145 * *$ & $8.7 \mathrm{E}-01 * *$ & $1.3082 * *$ & $2.7822 * *$ & $1.6784 * *$ & $1.6100 * *$ & $1.2237 * *$ & -0.7603 & $2.3560 * *$ \\
\hline Pop. Dens. & 0.0002 & $-0.0004 * *$ & -0.0001 & $-0.0034 * *$ & -0.0013 & 0.0007 & 0.0015 & $0.0123 * *$ & $0.0022 * *$ \\
\hline Manuf. Sh. & $0.7997 * *$ & $0.3407 * *$ & $1.2142 * *$ & 0.5072 & $0.8309 * *$ & 0.5563 & $1.1728 * *$ & $6.9721 * *$ & $1.5985 * *$ \\
\hline Manuf. Earn. & $0.0099 * *$ & $0.0035 * *$ & 0.0022 & 0.0010 & $0.0109 * *$ & $0.0169 * *$ & 0.0028 & $-0.0107 * *$ & $-0.0079 * *$ \\
\hline Export Exch. & $1.1 \mathrm{E}-05$ & $0.0015 * *$ & -0.0002 & -0.0015 & -0.0004 & 0.0007 & 0.0004 & $0.0050 * *$ & $-0.0022 * *$ \\
\hline ExpexchL1 & -0.0003 & $0.0012 * *$ & $0.0009 * *$ & -0.0011 & $0.0009 * *$ & 0.0004 & -0.0001 & $-0.0052 * *$ & $-0.0019 * *$ \\
\hline Import Exch. & $-0.0012 * *$ & $0.0026^{* *}$ & -0.0006 & $0.0026^{* *}$ & -0.0003 & $0.0026 * *$ & 0.0008 & $0.0024 * *$ & $-0.0018 * *$ \\
\hline ImpexchL1 & $-0.0015 * *$ & -0.0001 & $-0.0011 * *$ & $-0.0025 * *$ & 0.0005 & $-0.0018 * *$ & $-0.0036 * *$ & 0.0014 & -0.0010 \\
\hline Export Orient. & $0.3082 * *$ & -0.3309 & 0.1182 & -0.1375 & 0.0372 & -0.3025 & -0.1562 & 0.2745 & -0.0309 \\
\hline ExporientL1 & 0.0816 & -0.0755 & 0.0371 & $0.3760 * *$ & -0.0865 & 0.1464 & $-1.1341 * *$ & 0.4067 & 0.0404 \\
\hline Import Orient. & $-0.3912 * *$ & $-0.6353 * *$ & $0.6377 * *$ & $-0.8479 * *$ & $0.7823 * *$ & 0.6060 & -0.0230 & 0.1155 & -0.4695 \\
\hline ImporientL1 & -0.2580 & $0.2149 * *$ & -0.0677 & -0.0016 & 0.0282 & -0.0445 & $1.3529 * *$ & -0.2686 & -0.0389 \\
\hline
\end{tabular}

${ }^{\mathrm{a}}$ All models are estimated as a panel with fixed state and year effects.

**Significant at the .05 level.

Source: Authors' calculations at Center for Economic Studies, U.S. Census Bureau. 


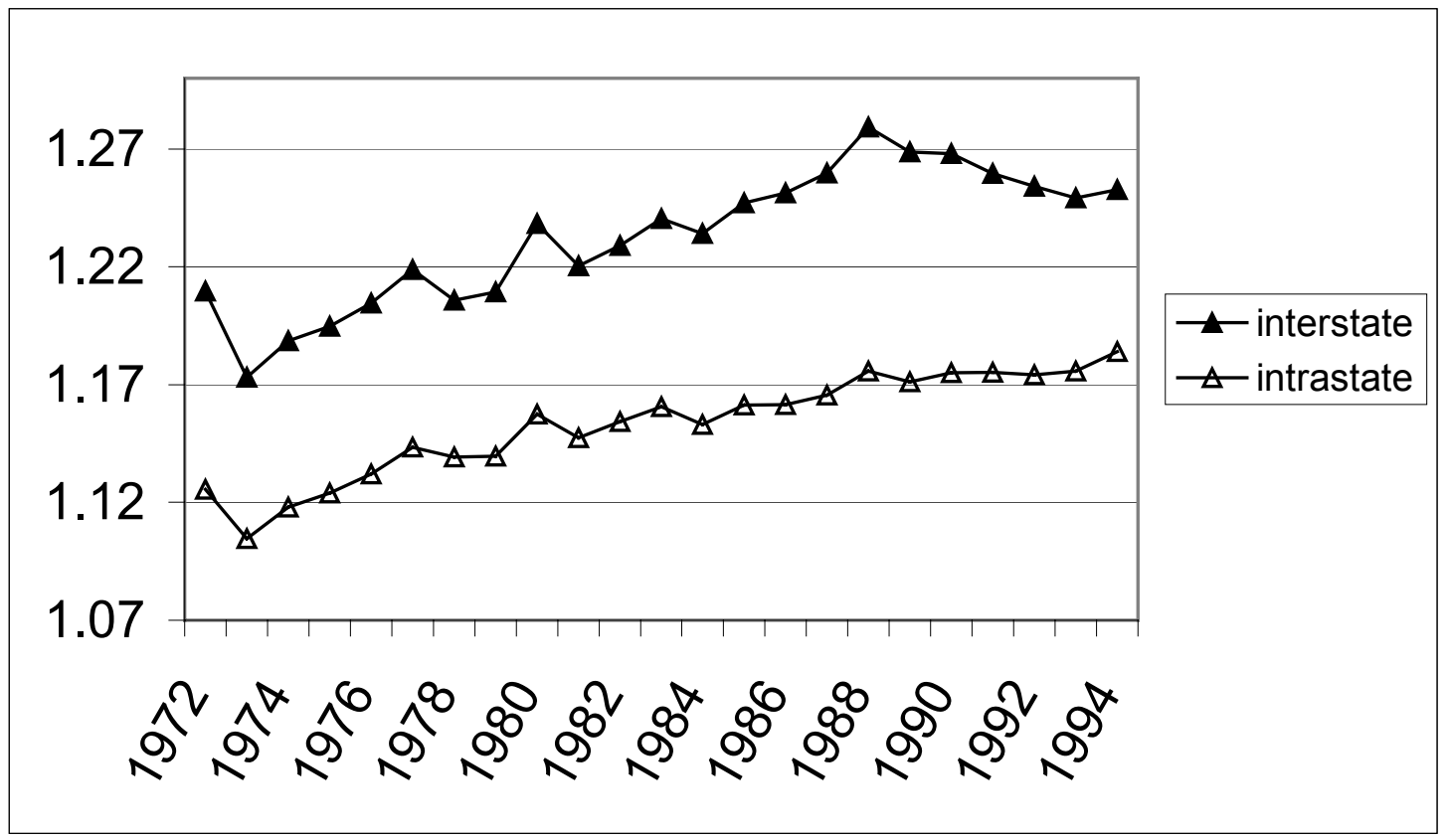

Figure 1: Mean Theil Inequality Values for the U.S. States, 1972-1994.

Source: Author's calculations using data from REIS (Census 2001). 


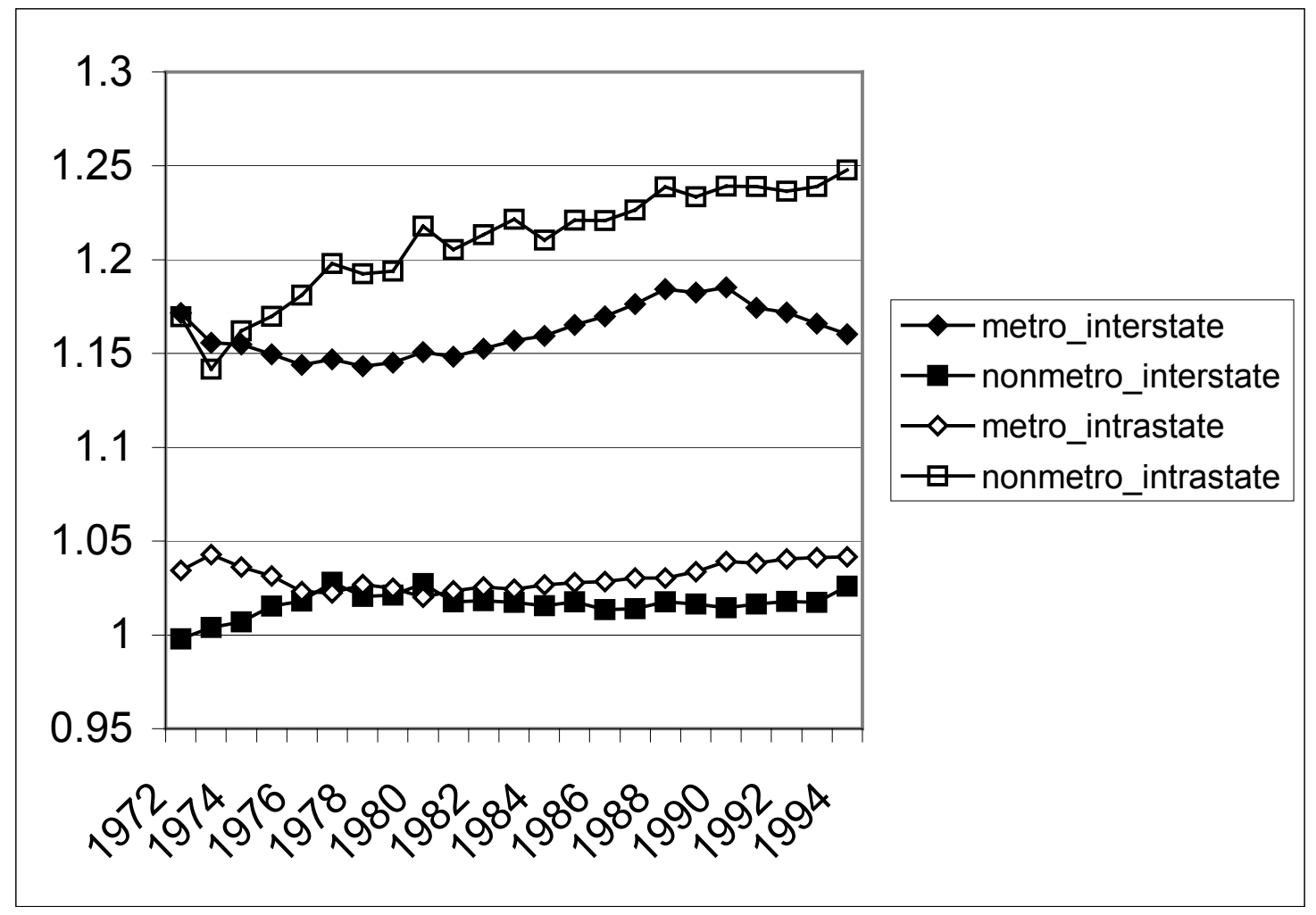

Figure 2. Mean Theil Inequality Values for the Metro and Nonmetro Portions of the U.S. States, 1972-1994. Source: Author's calculations using data from REIS (Census 2001). 


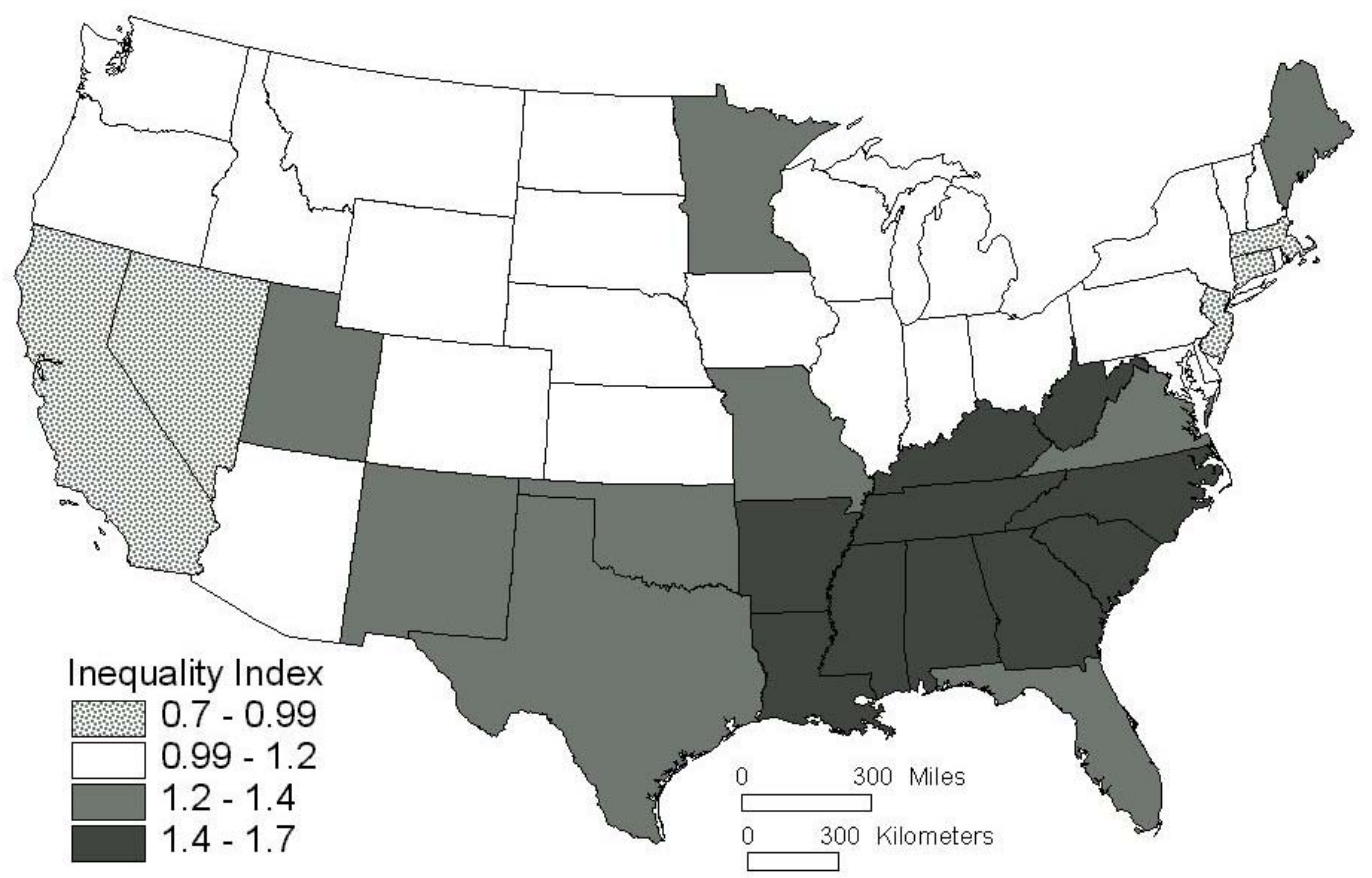

Figure 3. Interstate Inequality Values (Theil Index) for 1972.

Source: Author's calculations using data from REIS (Census 2001). 


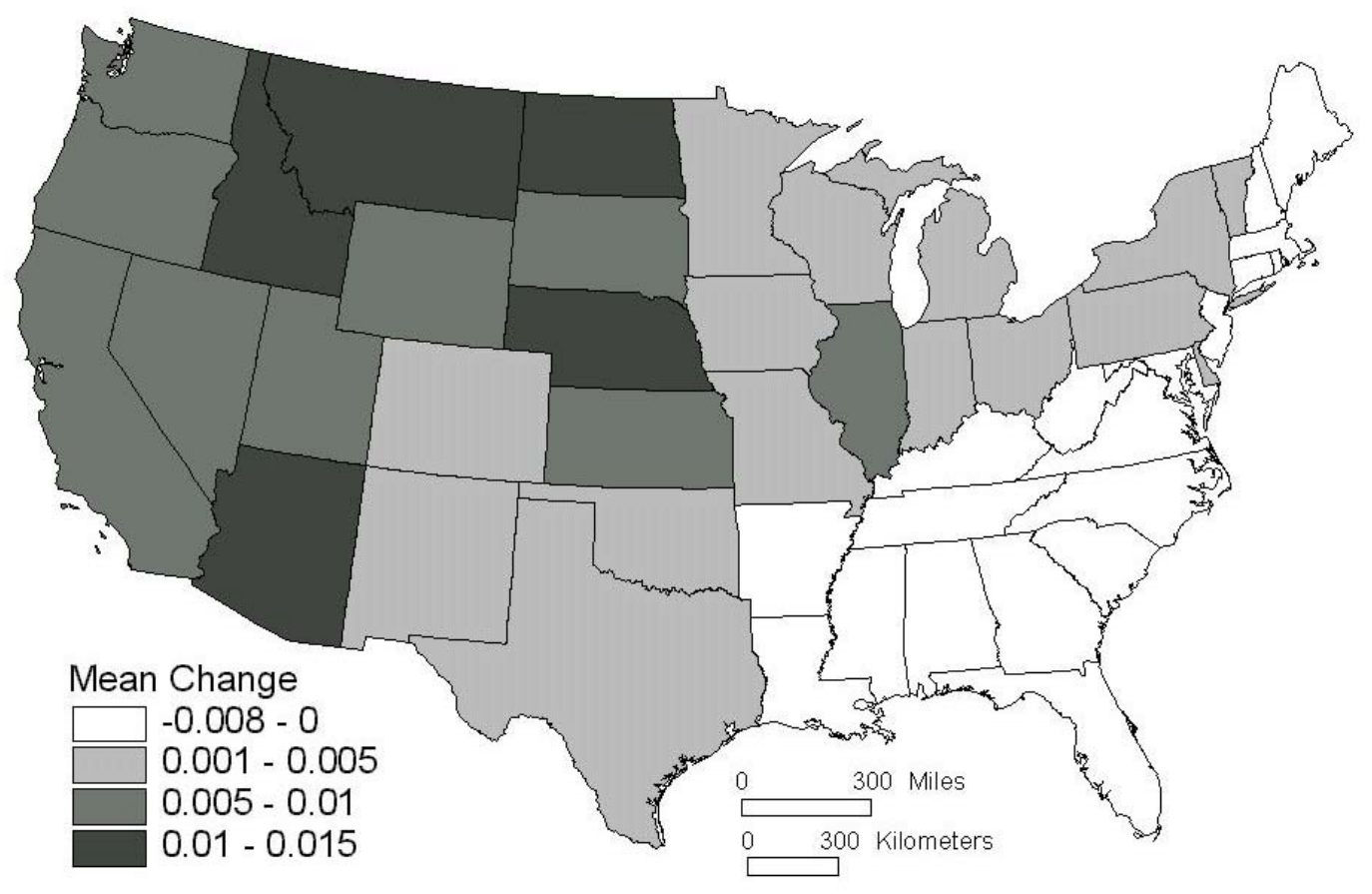

Figure 4. Mean Change in Interstate Inequality Values (Theil Index) from 1972 to 1994. Source: Author's calculations using data from REIS (Census 2001). 


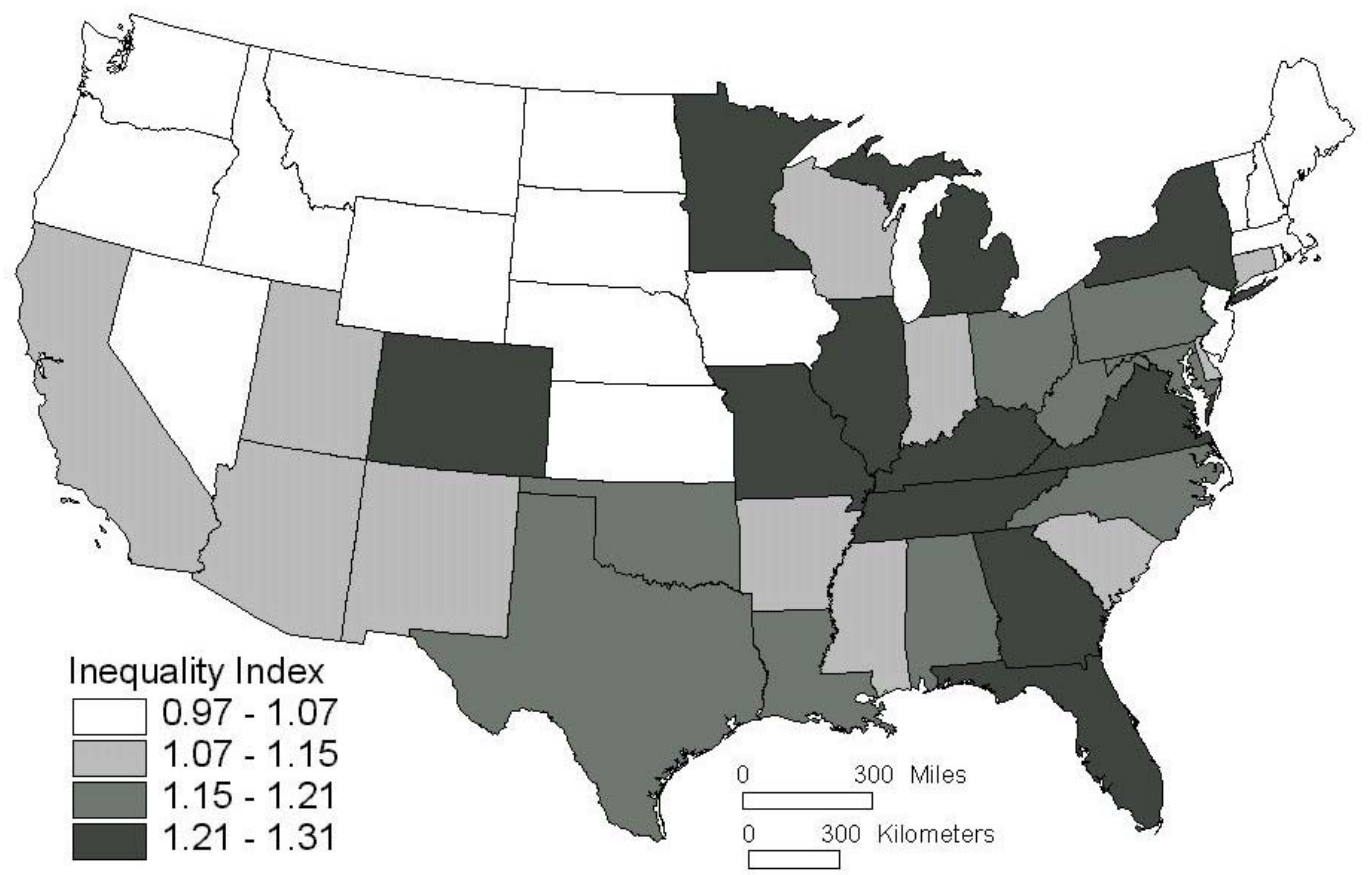

Figure 5. Intrastate Inequality Values (Theil Index) for 1972.

Source: Author's calculations using data from REIS (Census 2001). 


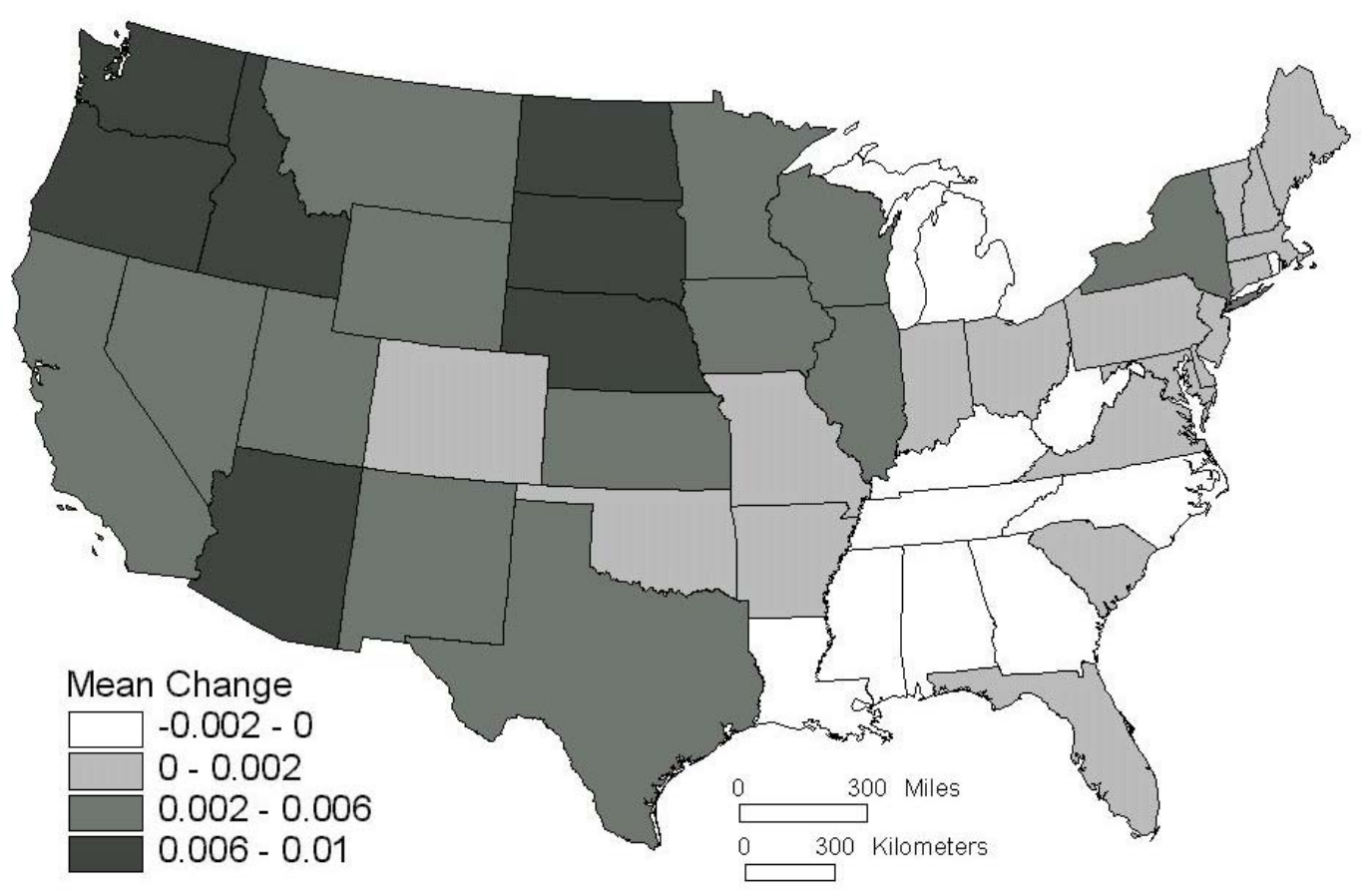

Figure 6. Mean Change in Intrastate Inequality Values (Theil Index) from 1972 to 1994. Source: Author's calculations using data from REIS (Census 2001). 